(c) 2018 - ISSN 1807-2577

\title{
Overview of the Brazilian odontological studies presented at a scientific meeting - SBPqO
}

\author{
Panorama de pesquisas odontológicas brasileiras apresentadas em reunião \\ científica - SBPqO
}

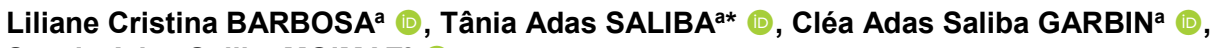
Suzely Adas Saliba MOIMAZa (1)

aUNESP - Universidade Estadual Paulista, Faculdade de Odontologia de Araçatuba, Araçatuba, SP, Brasil

How to cite: Barbosa LC, Saliba TA, Garbin CAS, Moimaz SAS. Overview of the Brazilian odontological studies presented at a scientific meeting - SBPqO. Rev Odontol UNESP. 2019;48:e20190082. https://doi.org/10.1590/1807-2577.08219

\begin{abstract}
Resumo
Introdução: É importante verificar os rumos da produção científica brasileira na área de odontologia e a conexão dos temas com a Agenda Prioritária em Pesquisa do Ministério da Saúde. Objetivo: Analisar o perfil da pesquisa odontológica das instituições de ensino superior apresentada em evento científico brasileiro. Material e método: Trata-se de análise documental dos trabalhos apresentados na $35^{a}$ reunião anual da SBPq0, na qual foram incluídos 3008 relacionados à pesquisas realizadas no Brasil e na categoria POAC analisou-se os 92 resumos dos anos de 2016 a 2018, verificando-se a subárea da saúde coletiva; tipo de estudo e testes estatísticos empregados. Resultado: Dos 3008 trabalhos, 63,6\% eram da região Sudeste; $67 \%$ de instituições públicas e apenas $38,5 \%$ foram financiados principalmente pelas agências de fomento FAPESP, CAPES e CNPq. Os títulos analisados no software IRAMUTEQ apresentaram predomínio dos temas relacionados à epidemiologia da cárie dentária; à qualidade de vida e às doenças crônicas não transmissíveis em crianças, gestantes, mulheres, idosos e indígenas. Na categoria POAC, $46 \%$ eram da promoção de saúde, $27 \%$ epidemiologia em saúde bucal, $17 \%$ educação em saúde e $10 \%$ atenção à saúde bucal. A análise estatística foi descrita em apenas 36\% dos resumos, nestes, $48 \%$ tratava-se de estudos transversais e $78 \%$ empregaram testes de associação. Conclusão: Houve predomínio da produção científica do país na região sudeste e nas instituições públicas. Observou-se conexão dos temas com os eixos da Agenda Prioritária em Pesquisa do Ministério da Saúde e na categoria POAC predominaram as pesquisa transversais de promoção de saúde.
\end{abstract}

Descritores: Indicadores de produção científica; pesquisa em odontologia; instituições acadêmicas.

\begin{abstract}
Introduction: It is important to verify the trends of Brazilian scientific production in the odontology area and the connection of study themes with the Ministry of Health's Priority Research Agenda. Objective: Analyze the dental research profile of higher-education institutions presented at a Brazilian scientific event. Material and method: This is a documentary analysis of the papers presented at the $35^{\text {th }}$ SBPq0 annual meeting, which included 3008 Brazilian studies. Also, 92 abstracts from the POAC category published between 2016 and 2018 were analyzed, verifying the subarea of public health, study type, and statistical tests employed. Result: Of the 3008 works, $63.6 \%$ were from the Southeast region, $67 \%$ were conducted in public institutions, and $38.5 \%$ were supported by funding agencies (FAPESP, CAPES and CNPq). The titles analyzed using IRAMUTEQ presented predominance of themes related to dental caries epidemiology, quality of life, and chronic non-communicable diseases in children, pregnant women, women, elderly, and indigenous people. In the POAC category, the studies addressed health promotion (46\%), oral health epidemiology (27\%), health education (17\%), and oral health care (10\%). Statistical analysis was described in only $36 \%$ of the abstracts, of which $48 \%$ were from cross-sectional studies and $78 \%$ from surveys that employed association tests. Conclusion: Brazilian scientific production in this filed came
\end{abstract}


predominantly from the Southeast region and public institutions. There was connection between the themes and the Priority Research Agenda, and cross-sectional studies addressing health promotion predominated in POAC.

Descriptors: Indicators of scientific production; odontology research; academic institutions.

\section{INTRODUCTION}

Scientific and technological research in health is considered indispensable for the improvement of health promotion, protection and recovery actions for the population. In Brazil, the construction of a science, technology and innovation system for health and the definition of research priorities have contributed to the strengthening of the Unified Health System (SUS) through the incorporation of new knowledge and technologies ${ }^{1}$.

As a result of research activities carried out at universities and research centers and institutes, scientific production has been disseminated through communication channels such as journals, events and books in order to democratize the knowledge produced, bringing information to the community, solving their problems, and fostering integrated and sustainable development ${ }^{2}$.

Scientific information is an important instrument for improving knowledge, techniques, and the use of technologies in dental practice. The use of the Internet makes patients more questioning about clinical decisions, thus in addition to professional experience, good practitioners should acquire knowledge on a continuous basis.

In Brazil, health research presents specific demands according to the country's epidemiological profile, which is characterized by presence of persistent problems, including neglected and tropical diseases, emerging epidemics, and non-communicable chronic diseases. Therefore, setting health research priorities is a difficult task, especially because health investment needs are numerous and the resources to address them are limited. However, identifying these priorities is fundamental to maximize the use of investments by responsibly directing public resources to meet the needs of the population.

The Priority Research Agenda (Agenda Prioritária em Pesquisa do Ministério da Saúde - APPMS) of the Brazilian Ministry of Health (MS) is a consultative document that, in addition to supporting the strategic planning of the MS, represents an important tool for articulation with research funding agencies and foundations, aiming at establishing partnerships (public and private) to leverage the funding of health research and direct efforts towards strategic and relevant topics for the SUS.

In order to align current health priorities with scientific, technological and innovative research activities and to direct resources available for investment in strategic research themes for the SUS, this agenda (APPMS) presents 172 lines of research distributed in 14 thematic axes: Environment, work and health; Pharmaceutical care; Post-incorporation assessment; Development of technologies and innovations in health; Chronic non-communicable diseases; Communicable diseases; Health economics and management; Work and health management; Health programs and policies; Women's health; Health of the black population and traditional communities; Health of the elderly; Health of indigenous people; Maternal and child health.

The APPMS thus confirms the commitment of the MS to the development of health research to integrate science, technology and innovation in the services provided to the Brazilian population'.

There is no denying that the scientific advance observed in Brazilian odontology, as well as in new technologies and equipment, elevates Brazil to a prominent position worldwide and gives research developed in the country considerable international respect ${ }^{2}$.

The International Association for Dental Research (IADR) is a US-based nonprofit organization whose goal is to advance research and increase knowledge for the improvement of oral health 
worldwide. Building on the support provided to the scientific community, facilitating communication, and publishing papers in the Journal of Dental Research, the IADR supports and represents the oral health research community. According to IADR bylaws, Divisions must hold at least one annual meeting, as the Association is responsible for organizing the IADR Annual World Meeting ${ }^{3}$.

Thus, the Brazilian Society of Dental Research (SBPqO), the Brazilian Division of the IADR, organizes the SBPqO Annual Meeting, which is the most important event in the country in the area of Odontology, with approximately 4000 participants including undergraduate and graduate students, professors and researchers, with representatives from all Brazilian states. Among the several modes of presentation, the category of Collective Action Dental Research (POAC) includes research projects of collective application presented under the panel mode that can effectively benefit the community and present social relevance with reflection on the quality of life of the population 4 .

In order to verify the trends of national research, the profile of dental studies, published in the proceedings of the 35th annual meeting of the Brazilian Society of Dental Research (SBPqO), conducted in Brazilian higher education institutions was accessed. The abstracts of works published under the POAC category between 2016 and 2018 were also analyzed.

\section{MATERIAL AND METHOD}

A documentary analysis was conducted on the studies published in the Brazilian Oral Research Supplement of the 35th annual meeting of the Brazilian Society of Dental Research (SBPqO). Also, abstracts from papers in the Collective Action Dental Research (POAC) category ${ }^{5-7}$ presented in the $33^{\text {rd }}, 34^{\text {th }}$ and $35^{\text {th }}$ SBPqO meetings, corresponding to the 2016, 2017 and 2018 editions, were assessed.

Initially, all abstracts were read in full and a database was constructed with the following variables: region of the country (North, Northeast, Midwest, Southeast and South); institution category (public and private); funding agency; mode of presentation at the meeting.

For the thematic analysis of the abstracts in the POAC category, the collective health subareas were divided into health promotion, health education, oral health care, and oral health epidemiology. Verification of the type of study (research methodology) and statistical tests used was performed through a search for words in the body text. Data were organized in Microsoft Office Excel 2013 software spreadsheet, analyzed, and presented using descriptive statistics.

The titles of the 3008 national works presented at the $35^{\text {th }} \mathrm{SBPqO}$ annual meeting were analyzed using the IRAMUTEQ (Interface de R pour lês Analyses Multidimensionnelles de Textes et de Questionnaires) software with the statistical functions Similarity and Word Cloud Analyses, whose inclusion criteria were active words, regardless of frequency of occurrence, excluding pronouns, verbs and connectors.

\section{RESULT}

In 2018, 3008 studies were carried out in Brazil, and their abstracts were published in the Brazilian Oral Research Supplement of the $35^{\text {th }}$ SBPqO annual meeting. Table 1 shows the distribution of these abstracts. 
Table 1. Numerical and percentage distribution of abstracts from Brazilian studies presented at the $35^{\text {th }}$ Annual Meeting of the SBPqO (2018), $(n=3008)$

\begin{tabular}{|c|c|c|}
\hline & $\mathbf{n}$ & $\%$ \\
\hline \multicolumn{3}{|l|}{ Region } \\
\hline Southeast & 1912 & 63.6 \\
\hline South & 509 & 16.9 \\
\hline Northeast & 366 & 12.2 \\
\hline Midwest & 126 & 4.2 \\
\hline North & 95 & 3.1 \\
\hline \multicolumn{3}{|l|}{ Institution Category } \\
\hline Public & 2028 & 67.4 \\
\hline Private & 980 & 32.6 \\
\hline \multicolumn{3}{|l|}{ Funding agency } \\
\hline No funding & 1849 & 61.5 \\
\hline With funding & 1159 & 38.5 \\
\hline FAPESP & 356 & 30.7 \\
\hline CAPES & 333 & 28.7 \\
\hline $\mathrm{CNPq}$ & 284 & 24.5 \\
\hline Other & 186 & 16.1 \\
\hline \multicolumn{3}{|l|}{ Mode of Presentation } \\
\hline Teaching Research & 38 & 1.3 \\
\hline POAC - Collective Action Dental Research & 30 & 1.0 \\
\hline Unilever Travel Award (Hatton) & 19 & 0.6 \\
\hline Colgate Odontologia Preventiva Award & 14 & 0.5 \\
\hline Joseph Lister Award & 02 & 0.1 \\
\hline Oral Presentation & 223 & 7.4 \\
\hline Scientific Forum & 28 & 0.9 \\
\hline Beginner Panel (Miyaki Issao Award) & 806 & 26.8 \\
\hline Aspirant and Effective Panel & 1795 & 59.7 \\
\hline Research Inside Industry & 05 & 0.2 \\
\hline Dental Cremer Award & 12 & 0.4 \\
\hline TCC - Undergraduate Thesis & 36 & 1.2 \\
\hline
\end{tabular}

$\mathrm{n}=$ number of national works presented at the $35^{\text {th }} \mathrm{SBPqO}$ annual meeting.

Although the Southeast region was responsible for most of the knowledge production in the country (63.6\%), discrepancy between the states that compose it was still observed: São Paulo (72.5\%), Minas Gerais (17.1\%), Rio de Janeiro (10.1\%), and Espírito Santo (0.3\%). All the other regions accounted for $36.4 \%$ of the research presented, and the smallest participation was from the North region (3.1\%).

The results of the papers presented in the POAC category from 2016 to 2018 indicated a reality in which the interest for the social was being consolidated as a study theme in the teaching and research institutions in this category; they were all from public institutions.

Of the 92 papers presented in this category in the last three years assessed, the subarea of health promotion accounted for $46 \%$, followed by oral health epidemiology (27\%), health education (17\%), and oral health care (10\%) (Table 2$)$.

Table 2. Distribution of abstracts from Brazilian studies in the POAC category, conducted between 2016 and 2018, presented at the SBPqO 2018 annual meeting according to the Collective Health subareas

\begin{tabular}{ccccc}
\hline Subarea & $\begin{array}{c}\mathbf{2 0 1 6} \text { to } \mathbf{2 0 1 8} \\
\text { n (\%) }\end{array}$ & $\begin{array}{c}\mathbf{2 0 1 6} \\
\text { n (\%) }\end{array}$ & $\begin{array}{c}\mathbf{2 0 1 7} \\
\text { n (\%) }\end{array}$ & $\begin{array}{c}\mathbf{2 0 1 8} \\
\text { n (\%) }\end{array}$ \\
\hline Health Promotion & $42(46 \%)$ & $07(25 \%)$ & $18(53 \%)$ & $17(57 \%)$ \\
Health Education & $16(17 \%)$ & $10(36 \%)$ & $03(09 \%)$ & $03(10 \%)$ \\
Oral Health Care & $09(10 \%)$ & $04(14 \%)$ & $01(03 \%)$ & $04(13 \%)$ \\
Oral Health Epidemiology & $25(27 \%)$ & $07(25 \%)$ & $12(35 \%)$ & $06(20 \%)$ \\
Total & $\mathbf{9 2}$ & $\mathbf{2 8}$ & $\mathbf{3 4}$ & $\mathbf{3 0}$ \\
\hline
\end{tabular}

$\mathrm{n}=$ number of abstracts from papers in the Collective Action Dental Research (POAC) category presented in the $33^{\text {rd }}$, $34^{\text {th }}$ and $35^{\text {th }}$ SBPqO meetings, corresponding to the 2016, 2017 and 2018. 
As for the study samples, participation of the following specific groups was observed: children (30\%), adolescents (8\%), the elderly (4\%) and pregnant women (4\%); the other surveys were conducted with the general population. Regarding the type of study, few papers included a description in the abstracts: cross-sectional (16), longitudinal/cohort (9), systematic review (4), and randomized clinical trial (4).

Statistical analysis was described in only $35 \%$ of the abstracts. In $78 \%$ of the studies, association tests, including the Chi-square and Mann-Whitney tests, were the most cited; $62 \%$ used multivariate and Poisson regression, and 6\% employed the Pearson and Spearman correlation tests.

\section{Results from the IRAMUTEQ Software}

Textual analysis of the 3008 titles of the presented studies showed occurrence of 44,904 words: 6113 distinct words and 3209 words with a single occurrence.

Use of the word cloud statistical function (Figure 1) showed that the words that emerged most frequently were "buccal" (219 occurrences); "dental" (177); "health" (171); "child" (129); "quality" (117), and "life" (101); connection with the other elements of graphic representation was verified in the similarity analysis (Figure 2).

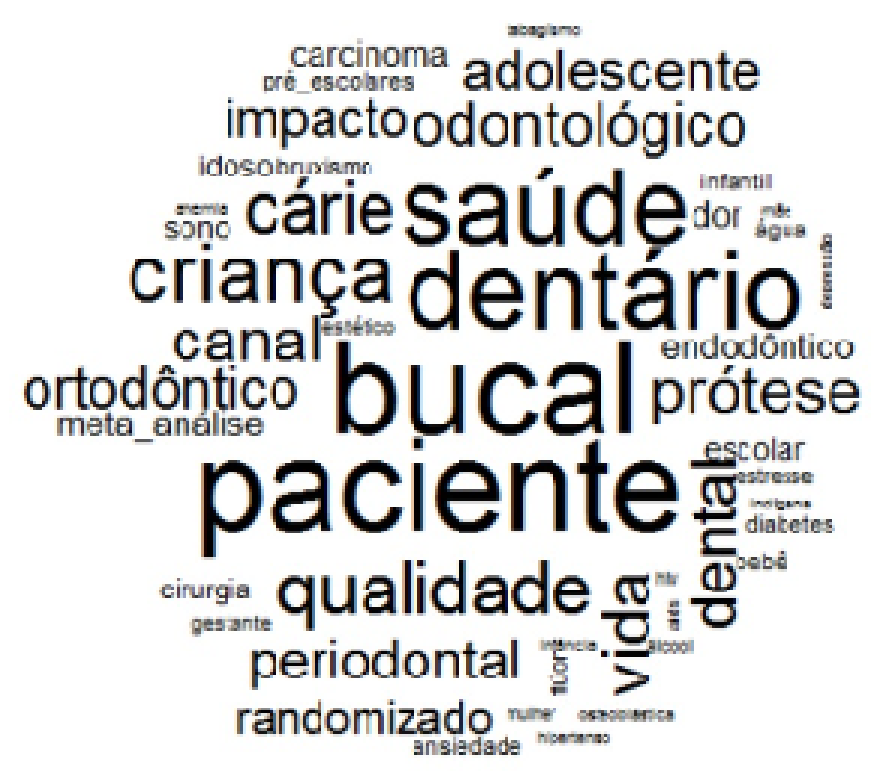

Figure 1. Word Cloud Analysis of the 3008 titles of papers published in the proceedings of the SBPqO 2018 annual meeting. 


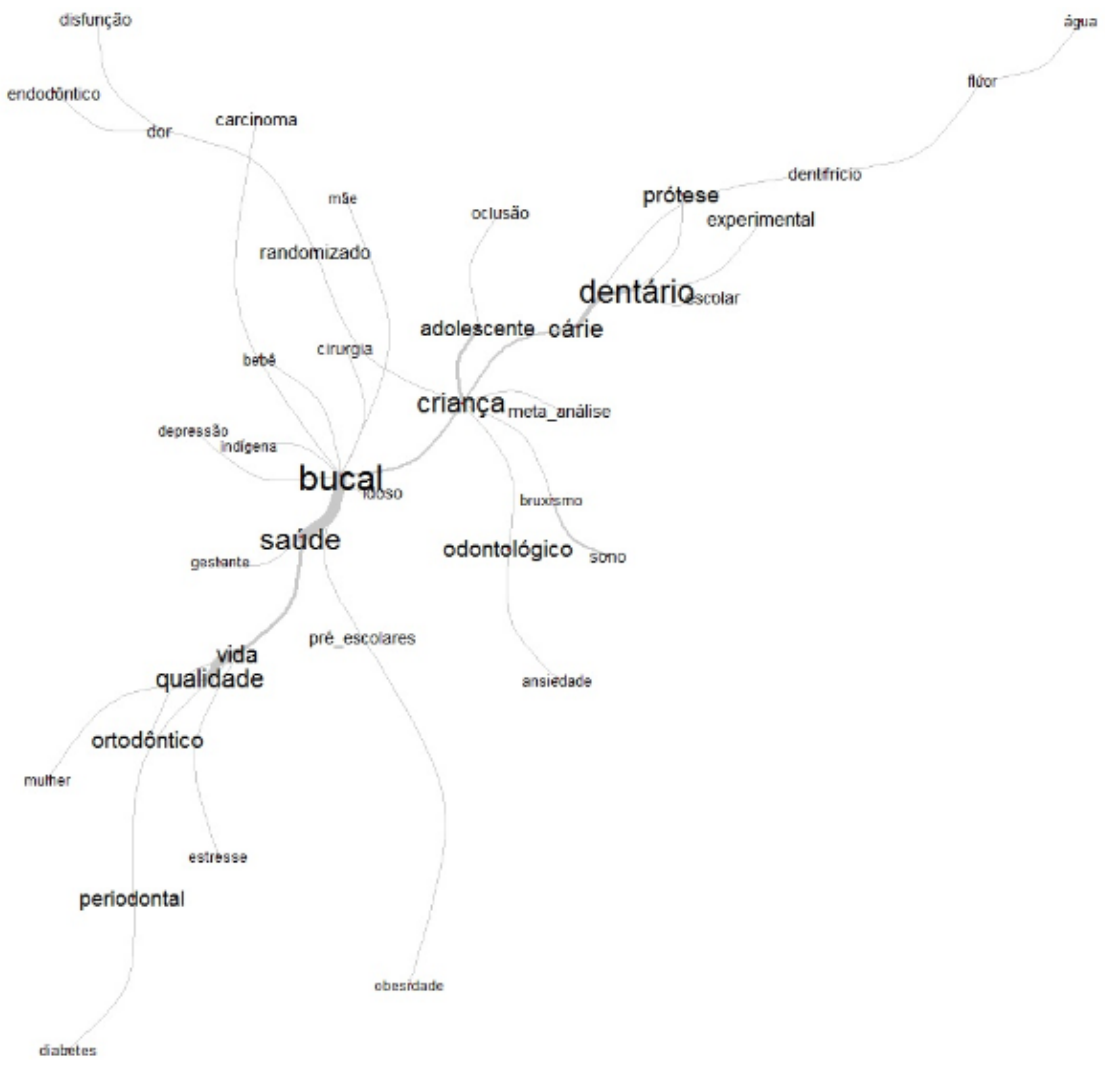

Figure 2. Similarity analysis of the 3008 titles of papers published in the annals of the SBPqO 2018 annual meeting.

\section{DISCUSSION}

The methodology employed in this survey allowed us to analyze the profile of the dental studies carried out in Brazilian educational and research institutions published in the annals of the $35^{\text {th }}$ meeting of the Brazilian Society of Dental Research (SBPqO) and the production of papers in the Collective Action Dental Research (POAC) category between 2016 and 2018. Predominance of the Southeast region, particularly of the state of São Paulo, was observed.

The predominance of public institutions and funding agencies was also highlighted, with most of the studies supported by the São Paulo State Research Support Foundation (FAPESP), the Coordination for the Improvement of Higher Education Personnel (CAPES), and the National Council of Scientific and Technological Development (CNPq) - results that corroborate those reported in previous studies ${ }^{8,9}$.

The spatial discrepancy of scientific research activities in Brazil was evidenced by the high concentration of publications and researchers in the Southeast region, especially the state capitals. For instance, the city of São Paulo concentrated approximately $20 \%$ of the Brazilian scientific production, and has climbed 21 positions in the list of the most knowledge-generating cities in the world in the past decade, and it is currently ranked among the 20 municipalities with the highest scientific production in the world ${ }^{10}$.

Likewise, the marked spatial heterogeneity of scientific production in the Southeast region has also been reported in previous studies, ${ }^{8,11,12}$. Over three quarters of the Brazilian studies published between 2007 and 2009 were from the Southeast and South regions, with the Midwest and North regions accounting for less than $10 \%$.

Although there has been a process of internalization of research activities through incentives from funding agencies, announcements from CAPES and CNPq, with the qualified expansion of 
graduate studies in all Brazilian states, scientific production in this field is still concentrated in the Southeast region, and data from the CAPES Quadrennial Assessment Report (2013-2016) confirmed the need to accelerate decentralization of graduate education ${ }^{13}$.

The CNPq "Casadinho Program" aimed to promote the strengthening of research groups and consolidation of stricto sensu graduate studies programs by supporting inter- and/or intra-regional cooperation between groups linked to non-consolidated graduate studies programs (concepts 3 or 4 obtained in the last Capes/MEC assessment) of national public higher education and research institutions in the North, Northeast and Midwest regions, including the State of Espírito Santo, and groups linked to consolidated programs (concepts 6 or 7 obtained in the latest Capes assessment) from any region of the country. The CNPq "Casadinho Program" has the following main objectives: implementation and recovery of research infrastructure, increased formation and qualification of qualified human resources, improvement of graduate studies programs, and greater regional distribution of research excellence centers in the country ${ }^{14}$.

The growing trend of Brazilian scientific production is associated with investment from the State, both in the qualification of human capital and in the improvement of the infrastructure of universities and research institutes, due to the closer relationship between educational institutions and the SUS, together with greater interest in social issues $12,15,16$. The highlight of the state of São Paulo in the national scientific collaboration network is associated with the scientific infrastructure installed in the state and with the presence of internationally recognized universities and collaborative research networks involving researchers supported by Research Programs and Projects ${ }^{17}$.

One of the limitations of this study in data analysis was due to the absence of the keywords described in the abstracts. Keywords are important primary tools employed in indexing searches. Through them, it would be possible to perform a more accurate thematic analysis.

Another limitation was the absence of the area in which the papers were submitted for presentation at the scientific event. The description of the area would enable exploratory analysis of the distribution of the subareas of odontology, since collective health and social odontology are presented only as behavioral science and, although the papers presented in the POAC category, with oral or panel presentation, are on collective action, this theme was also distributed in the other categories of the event.

In addition, few studies provided a description of the statistical analyses used; however, after reading of the abstracts in full, it was possible to identify the type of study: qualitative research, literature review, experience report, and descriptive analysis, with only absolute and relative data mentioned.

Results of the analysis using the IRAMUTEQ software showed that the word "bucal", cited in the titles of the abstracts, configured the central part of the themes from which branches with significant terms such as "health", "quality", "life" and "child" shown in the similarity tree, suggesting that, in general, oral health issues in children, pregnant women, women, the elderly, and indigenous people were associated with the impact of oral health on quality of life and chronic non-communicable diseases such as diabetes, obesity, stress, and anxiety.

It is worth mentioning the participation of undergraduate students in $28 \%$ of the works published in the beginner panel (Miyaki Issao Award) and TCC (Undergraduate Thesis) categories in 2018, as well as the fact that, despite representing a small percentage of the papers presented at the SBPqO meetings, the academic collaboration in the POAC category brings subsidy to the process of formulating public policies, which points to the need for growth in the number of works developed and published in this category. 


\section{CONCLUSION}

Regional discrepancy is still observed in scientific production in Brazil, with concentration in the Southeast region, particularly in the state of São Paulo, and predominance of public institutions. Analysis using the IRAMUTEQ software showed that most of the themes of the presented papers are related to dental caries epidemiology, quality of life, and chronic non-communicable diseases in the following main groups: children, pregnant women, women, the elderly, and indigenous people. The themes showed connection with the axis of the Ministry of Health's Priority Research Agenda. In the POAC category, there was predominance of cross-sectional research in the health promotion subarea.

\section{REFERENCES}

1. Brasil. Ministério da Saúde. Agenda de prioridades de pesquisa do Ministério da Saúde (APPMS). Brasília: Ministério da Saúde; 2018.

2. Sígolo BOO, Casarin HCS. Destaque da produção brasileira em odontologia no cenário mundial e a influência no comportamento informacional do profissional cirurgião-dentista. Revista EDICIC. 2011;1(4):389-407.

3. International Association for Dental Research - IADR [Internet]. 2019 [cited 2019 Mar 14]. Available from: http://www.iadr.com

4. Sociedade Brasileira de Pesquisa Odontológica - SBPqO [Internet]. 2019 [cited 2019 Mar 21]. Available from: http://www.sbpqo.org.br

5. Sociedade Brasileira de Pesquisa Odontológica - SBPqO. 33aㅡ Reunião Anual da Sociedade Brasileira de Pesquisa Odontológica. São Paulo: SBPqO; 2016. Resumos dos trabalhos.

6. Sociedade Brasileira de Pesquisa Odontológica - SBPqO. 34ª Reunião Anual da Sociedade Brasileira de Pesquisa Odontológica. São Paulo: SBPq0; 2017. Resumos dos trabalhos.

7. Sociedade Brasileira de Pesquisa Odontológica - SBPqO. 35a Reunião Anual da Sociedade Brasileira de Pesquisa Odontológica. São Paulo: SBPq0; 2018. Resumos dos trabalhos.

8. Aquino SN, Martelli DR, Bonan PRF, Laranjeira AL, Martelli H Jr. Scientific production in dentistry and its relation with research funding agencies. Arq Odontol. 2009;45(3):142-6.

9. Dutra DM, Almeida Freires I, Santos Neves R, Lima DMB, Padilha WWN. Aspectos institucionais e metodológicos dos resumos brasileiros publicados na 85a Reunião Anual Mundial da IADR - 2007. Rev Bras Ciênc Saúde. 2012;16(4):545-52. http://dx.doi.org/10.4034/RBCS.2012.16.04.08.

10. Royal Society. Knowledge, networks and nations: global scientific collaboration in the 21st century [Internet]. London: The Royal Society; 2011 [cited 2019 Apr 20]. Available from: https://royalsociety.org/policy/ projects/ knowledge-networks- ations/report/

11. Sidone OJG, Haddad EA, Mena-Chalco JP. Science in brazilian regions: development of scholarly production and research collaboration networks. Transinformacao. 2016;28(1):15-32. http://dx.doi.org/10.1590/2318-08892016002800002.

12. Zanini TI, Carraro DS, Oliveira KV, Leonardi DP, Gabardo MCL. Dental research on collective health at the meeting of the Sociedade Brasileira de Pesquisa Odontológica (Brazilian Society of Dental Research): 14-year cut-off point. RSBO. 2016 Oct-Dec;13(4):255-9. http://dx.doi.org/10.21726/rsbo.v13i4.347.

13. Coordenação de Aperfeiçoamento de Pessoal de Nível Superior. Relatório de avaliação 2013-2016 [Internet]. Brasília: CAPES; 2017 [cited 2019 Mar 30]. Available from: http://avaliacaoquadrienal.capes.gov.br/home/sai-o-resultado-da-1a-etapa-da-avaliacao-quadrienal2017 
14. Fundação Capes. Chamada Pública MCTI/CNPq/MEC/Capes. Ação transversal no 06/2011: Casadinho/Procad. Brasília: CAPES; 2017 [cited 2019 Mar 30]. Available from: http://www.capes.gov.br/pt/bolsas/programas-estrategicos/procad/casadinho-procad

15. Iriart JAB, Deslandes SF, Martin D, Camargo KR Jr, Carvalho MS, Coeli CM. Evaluation of scientific production in different subareas of public health: limits of the current model and contributions to the debate. Cad Saude Publica. 2015 Out;31(10):2137-47. http://dx.doi.org/10.1590/0102311X00065515. PMid:26735381.

16. Helene AF, Ribeiro PL. Brazilian scientific production, financial support, established investigators and doctoral graduates. Scientometrics. 2011 Nov;89(1):677-86. http://dx.doi.org/10.1007/s11192-0110470-2.

17. Fundação de Amparo à Pesquisa do Estado de São Paulo. Indicadores de ciência, tecnologia e inovação em São Paulo 2010. São Paulo: Fapesp; 2011. Análise da produção científica a partir de publicações em periódicos especializados; p. 1.

\section{CONFLICTS OF INTERESTS}

The authors declare no conflicts of interest.

\section{*CORRESPONDING AUTHOR}

Tânia Adas Saliba, UNESP - Universidade Estadual Paulista, Faculdade de Odontologia de Araçatuba, Rua José Bonifácio, 1193, 16015-050 Araçatuba - SP, Brasil, e-mail: tania.saliba@unesp.br

Received: August 12, 2019

Accepted: August 28, 2019 